\title{
Infrared Stimulated Luminescence and Thermoluminescence Dating of Loess from Lanzhou, China
}

\author{
Sumiko Tsukamoto*1, Hitoshi Fukusawa*1, Yugo Ono*2 \\ and Xiao-Min Fang*3
}

\begin{abstract}
Loess samples from the 22-m-thick Shajinping section on the second-lowest terrace of the Yellow River in Lanzhou, Gansu Province, China, were dated by infrared stimulated luminescence (IRSL) and by thermoluminescence (TL).

Isothermal preheating tests for IRSL dating were made at two different temperatures, 120 and $160^{\circ} \mathrm{C}$, to determine the preheating condition most appropriate for isolating the stable IRSL signal. The irradiated/non-irradiated IRSL ratio reaches a plateau after preheating for 24 to 144 hours at $120^{\circ} \mathrm{C}$, or for 1.5 to 5 hours at $160^{\circ} \mathrm{C}$. The IRSL signal with preheating at $120^{\circ} \mathrm{C}$. was enhanced by increasing the artificial gamma irradiation, but the IRSL signal with preheating at $160^{\circ} \mathrm{C}$ was saturated at a low dose, so it was difficult to use the dose-response curve to calculate an equivalent dose $\left(D_{\mathrm{E}}\right)$. The $120^{\circ} \mathrm{C}$ preheating was determined to be most appropriate ; therefore, all samples were preheated at $120^{\circ} \mathrm{C}$ for 96 hours before IRSL measurement.

Except for one sample, the IRSL and TL dates for samples from the upper $12 \mathrm{~m}$ of the section agreed with each other, within the error range, but the IRSL dates for samples from the lower $9 \mathrm{~m}$ of the section were younger than the TL dates. This discrepancy between IRSL and TL dates might have been caused by underestimation of the IRSL dates, due to the samples' low saturation value of IRSL $D_{\mathrm{E}}$ S at about 200 Gy. The IRSL and TL dates indicate that the loess deposition rate during the last 60 ka has changed several times. A very high loess deposition rate was obtained for the late marine isotope stage (MIS) 3 , whereas the deposition rate seems to have been lower during MIS 2.
\end{abstract}

Key Words : loess, paleosol, IRSL, TL, preheat plateau

\section{Introduction}

The western part of the Chinese Loess Plateau is characterized by a high sediment deposition rate and weak pedogenesis (Fang et al., 1994). The Loess Plateau of the Lanzhou area has the thickest loess deposits in the world, and these have great potential for detecting past environmental changes, with high time resolution (Burbank and Li, 1985 ; Li et al., 1990). The magnetic susceptibility (MS), carbonate contents, and soil color of loess at the Shajinping section on the second-lowest (T2) terrace of the Yellow River in Lanzhou have been measured at 2.5 to $5-\mathrm{cm}$ intervals, and high-resolution environmental changes corresponding to Dansgaad-Oeschger cycles and long-term Bond cycles were observed (Fukusawa and Yamada, 1998 ; Fang et al., 1999 ; Yamada et al., 1999). There is, however, only limited information on

Received December 16, 2000. Accepted June 23, 2001.

*1 Department of Geography, Tokyo Metropolitan University. 1-1 Minamiosawa, Hachioji, Tokyo, 192-0397, Japan. E-mail :

*2 Graduate School of Environmental Earth Science, Hokkaido University. Kita 10, Nishi 5, Kita-ku, Sapporo, 0600810, Japan.

*3 Department of Geography, Lanzhou University. Lanzhou, Gansu 730000, P.R. China. 
the chronology of the loess and paleosols. Fang et al. (1999) established the chronology of the Shajinping section, based on tentative IRSL dates without a preheating test (Tsukamoto et al., 1999) together with ${ }^{14} \mathrm{C}$ ages of paleosols, and concluded that the section consists of loess deposited during the last $60 \mathrm{ka}$. On the other hand, Fukusawa and Yamada (1998) and Yamada et al. (1999) made a standard composite pattern of MS and lightness $\left(\mathrm{L}^{*}\right)$ of Chinese loess during the last $140 \mathrm{ka}$ based on values for loess of known age in Linxia, Central China. They compared the pattern of MS and $\mathrm{L}^{*}$ of the Shajinping section with the standard pattern and determined that the section consisted of loess deposited during the last $75 \mathrm{ka}$.

The combination of the infrared stimulated luminescence (IRSL) and thermoluminescence (TL) dating methods using fine polymineral grains has become a powerful tool in determining the ages of late Pleistocene loess deposits $(e$. g., Musson et al., 1994 ; Richardson et al., 1997 ; Frechen, 1999). The aim of this study is to construct a detailed chronology of the section using IRSL and TL dating methods.

In IRSL dating, preheating of the samples is necessary before IRSL measurements, because both non-irradiated and irradiated IRSL signals have thermally unstable components. IRSL dating studies using polymineral grains have used various preheating conditions: $220^{\circ} \mathrm{C}$ for 10 minutes (Richardson et al., 1997) ; $160^{\circ} \mathrm{C}$ for 5 or 16 hours (Forman et al., 1994), $150^{\circ} \mathrm{C}$ for 16 hours (Frechen, 1999), and $140^{\circ} \mathrm{C}$ for 16 hours (Musson et al., 1994). This indicates that the thermal stability of the IRSL signal and the appropriate preheating temperature and duration vary from sample to sample. Therefore, using the method of Stokes (1992), isothermal preheating tests were conducted at two different temperatures to determine suitable preheating conditions for IRSL dating of loess from Lanzhou.

\section{Samples}

Ten loess samples (SJP-1, 5, 6, 9, 11, 12, 13, 14, $16,17)$ were collected from the Shajinping section in Lanzhou, Gansu Province, China, where a 22-m-thick section of loess is exposed on the second-lowest terrace of the Yellow River (Fig.

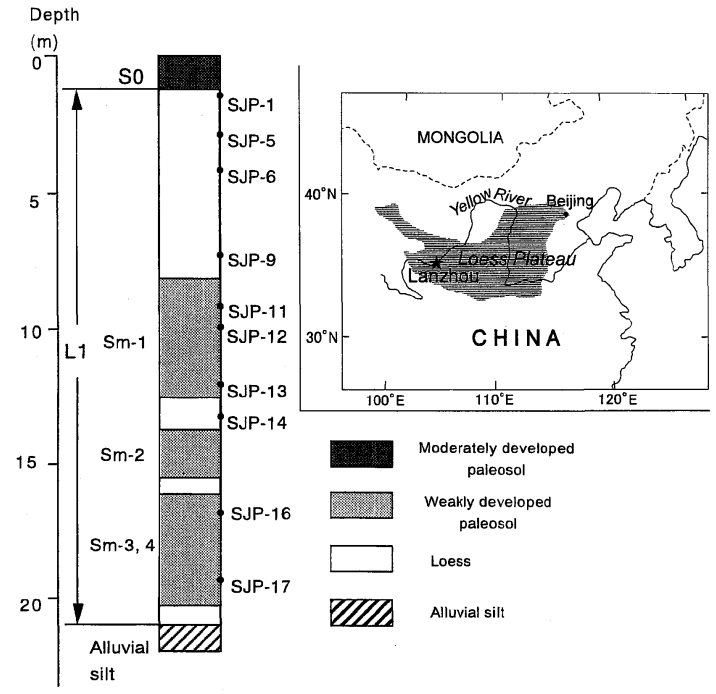

Fig. 1 Loess stratigraphy at Shajinping (Fang et al., 1999) and sample locations

$\mathrm{S} 0$ and $\mathrm{Sm}-1,-2,-3,-4$ are considered to be Holocene and interstadial soils. L1 is correlated with Malan Loess, which was deposited during the last glacial period. The inset shows the extent of the Chinese Loess Plateau (shaded area) and the location of Lanzhou.

1). The section consists of alluvial silts at the bottom, Malan loess (L1) in the middle, and a moderately developed S0 paleosol at the top. Weakly developed paleosols (Sm-1, 2, 3, 4) are present in the lower half of the L1 loess. All samples were collected by pushing opaque plastic tubes into the exposure.

\section{Methods}

\section{Sample preparation}

Samples were treated with $10 \%$ hydrogen peroxide and $10 \%$ hydrochloric acid, then treated with $2 \%$ Calgon to disaggregate the grains. The 4 to $11-\mu \mathrm{m}$ grain-size fraction was separated using Stokes' Law. Separated polymineral samples were suspended in acetone, and then deposited onto aluminum disks in test tubes. The amount of sample on each disk was less than $1 \mathrm{mg}$. All preparations were made in subdued red light:

\section{Preheat test}

An isothermal preheating test to determine the most appropriate preheating conditions 
was made at two different temperatures, 160 and $120^{\circ} \mathrm{C}$, using sample SJP-6. Four irradiated and four non-irradiated disks were prepared, preheated at each temperature and for different durations, and the ratio of the nonirradiated and irradiated IRSL intensities as a function of time spent at $160^{\circ} \mathrm{C}$ or $120^{\circ} \mathrm{C}$ was plotted. The IRSL signals were measured using a hand-made OSL/IRSL reader. The reader consists of a Hamamatsu R647-04 photomultiplier and 4 IR-emitting diodes (GaAlAs diodes, Hamamatsu L2690-02, 890 $\pm 50 \mathrm{~nm}$ ) with a power of less than $18 \mathrm{~mW} / \mathrm{cm}^{2}$. The detection filters used were Corning 4-96, HOYA B-370, and HOYA HA-30 filters. All of the measurements were made using a 100 -second IR expo-
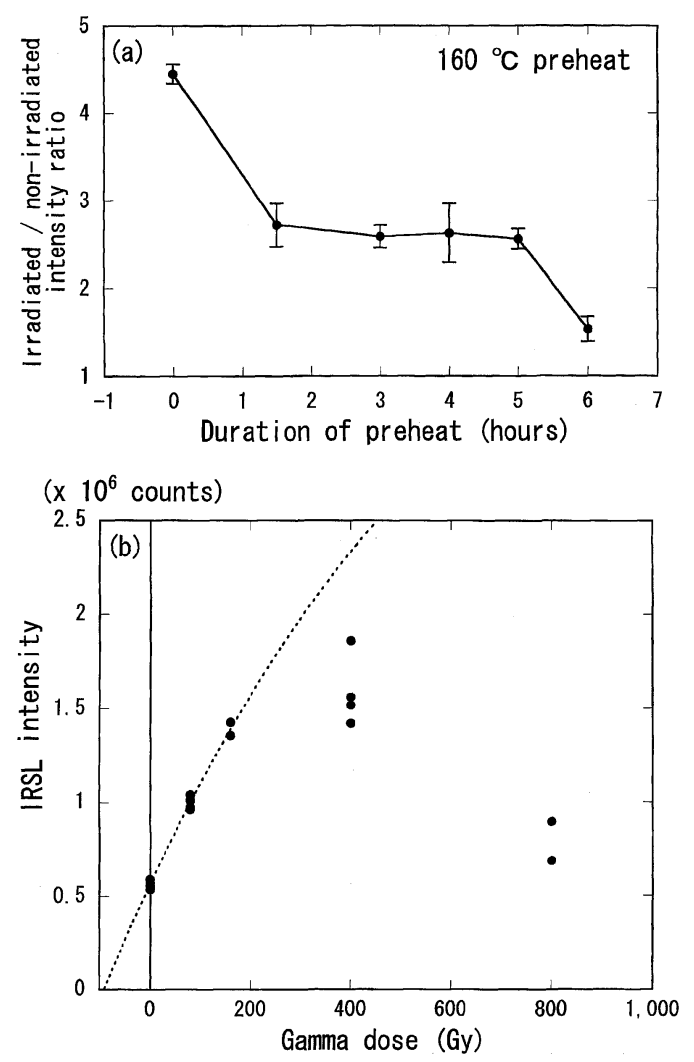

Fig. 2 Results of preheat test at $160^{\circ} \mathrm{C}$

(a) IRSL ratio of non-irradiated to gammairradiated aliquots of sample SJP-6 as a function of preheating duration at $160^{\circ} \mathrm{C}$

(b) Dose-response curve of IRSL signal intensity for a sample preheated at $160^{\circ} \mathrm{C}$ for 4 hours sure at room temperature.

Preheating at $160^{\circ} \mathrm{C}$ was tested first. The irradiated/non-irradiated IRSL intensity ratio showed a plateau between 1.5 and 5 hours at $160^{\circ} \mathrm{C}$ (Fig. $2-\mathrm{a}$ ), indicating that only the stable IRSL signal remained after preheating for this length of time. Next, SJP-6 sample disks were irradiated with different gamma doses $(0-800$ $\mathrm{Gy})$ to create the dose-response curve that was used to calculate the equivalent dose $\left(D_{\mathrm{E}}\right)$ by extrapolating the curve to the intercept of the dose axis. The plot of the IRSL intensity as a function of the irradiated gamma dose after preheating at $160^{\circ} \mathrm{C}$ for 4 hours (Fig. 2-b) shows

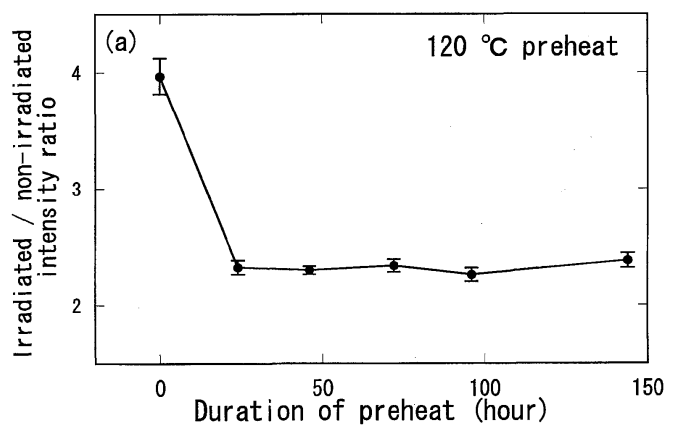

(x $10^{5}$ counts)

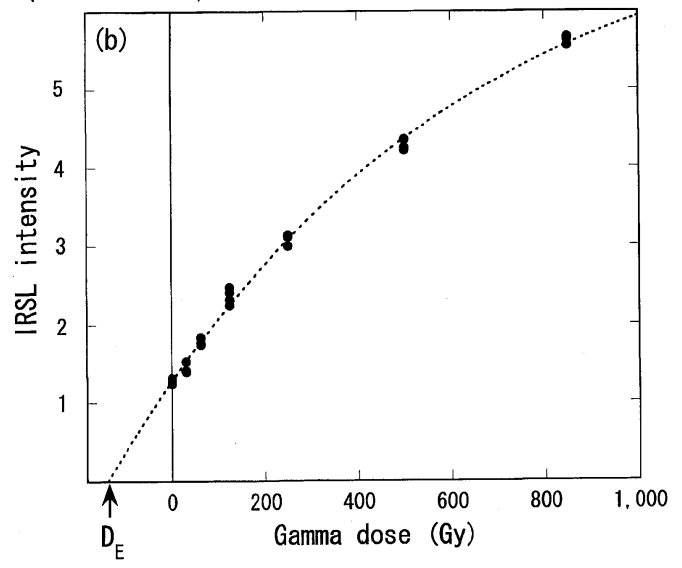

Fig. 3 Results of preheat test at $120^{\circ} \mathrm{C}$

(a) IRSL ratio of non-irradiated to gammairradiated aliquots of sample SJP-6 as a function of preheating duration at $120^{\circ} \mathrm{C}$

(b) Dose-response curve of IRSL signal intensity for a sample preheated at $120^{\circ} \mathrm{C}$ for 96 hours

$D_{\mathrm{E}}$ is obtained by fitting the dose-response curve and extrapolating to the dose axis. 
that IRSL intensity increased at lower doses $(80$ and $160 \mathrm{~Gy}$ ), but decreased at higher doses (400 and $800 \mathrm{~Gy}$ ), compared with the expected dose response curve (dotted line). This decrease in IRSL intensity was due to radiation quenching (Huntley et al., 1996), which should be avoided by changing the preheating conditions.

The lower preheating temperature $\left(120^{\circ} \mathrm{C}\right)$ was then tested. The irradiated/non-irradiated intensity ratio after preheating at $120^{\circ} \mathrm{C}$ for different periods (Fig. 3-a) showed a plateau between 24 and 144 hours. The dose-response curve after 96 hours of preheating at $120^{\circ} \mathrm{C}$ showed that the IRSL signal increased with increasing irradiation dose (Fig. 3-b). The optimal preheating condition for all samples was therefore $120^{\circ} \mathrm{C}$ for 96 hours.

3. IRSL and TL measurements and equivalent dose $\left(D_{\mathrm{E}}\right)$ determination

Both IRSL and TL measurements for $D_{\mathrm{E}}$ determination were performed on an automated Daybreak 1150 TL/OSL reader, with two HOYA U-340 detection filters, at Nara University of Education. The duration of IR illumination was 90 seconds for each measurement ; the integrated IRSL intensity of the first $20 \mathrm{sec}$ onds was used to create a dose-response curve, and that of the last 10 seconds, considered to be background, was subtracted. TL glow curves were obtained by heating the disks to $450^{\circ} \mathrm{C}$ at a rate of $5^{\circ} \mathrm{C} / \mathrm{sec}$ in a nitrogen atmosphere. An integrated TL intensity of $280-350^{\circ} \mathrm{C}$ was used.

The IRSL and TL $D_{\mathrm{ES}}$ were obtained by additive dose and total bleach methods, respectively. Twenty-eight aliquots were prepared for each sample, and these were split into seven groups. One group was non-irradiated, while the disks in the other 6 groups were irradiated with different gamma doses from 30 to $850 \mathrm{~Gy}$ with a calibrated ${ }^{60} \mathrm{Co}$ gamma-ray source at a rate of $17 \mathrm{~Gy} / \mathrm{hr}$. All of the aliquots were preheated at $120^{\circ} \mathrm{C}$ for 96 hours, according to the results of the preheating test, and were then used for IRSL measurements. IRSL signals irradiated with different gamma doses $(0-850$ Gy) are shown in Figure 4-a. $D_{\mathrm{ES}}$ for IRSL dating were obtained by plotting signal intensity as a function of gamma-ray dose, and by applying a single saturation function,
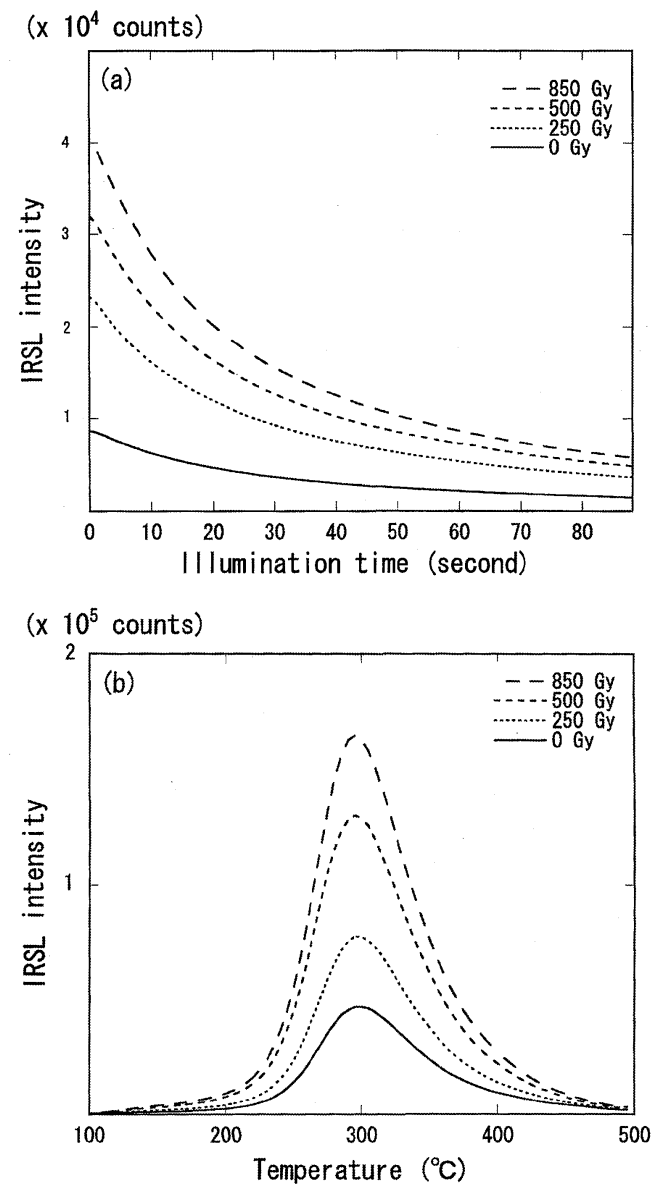

Fig. 4 IRSL and TL signals of SJP-9

(a) Non-irradiated and irradiated IRSL shinedown curves

(b) Non-irradiated and irradiated TL glow curves

$$
I=I_{\max }\left[1-\exp \left\{\mathrm{a}\left(Q+D_{\mathrm{E}}\right)\right\}\right]
$$

where $I$ is the IRSL intensity, $I_{\max }$ is the saturation intensity, $Q$ is the gamma dose, and $D_{\mathrm{E}}$ is the gamma-equivalent accumulated dose. $D_{\mathrm{E}}$ was found by extrapolating a fitted growth curve to the intercept of the dose axis (Fig. 3-b). The calculation was made using the program Dose.exe, written by Brumby (1992).

The same sample disks were used for TL measurements after measuring the IRSL. Nonirradiated and gamma-irradiated TL glow curves are shown in Figure $4-\mathrm{b}$. $D_{\mathrm{E}}$ for TL using the total bleach method is usually calcu- 
lated by fitting the growth curve of TL intensity as a function of radiation dose, and extrapolating the curve to the intercept with a horizontal line representing the residual TL intensity. The residual TL signal was measured after bleaching non-irradiated disks for 16 hours under sunlight, and the residual TL signal of all of the samples was negligible. The TL $D_{\mathrm{ES}}$ of the samples were thus calculated using the same method as the IRSL $D_{\mathrm{ES}}$, by extrapolating the dose response curve to the dose axis.

\section{Dose rate determination}

The dose rate was calculated from the U, Th, and $\mathrm{K}$ concentrations in the samples using the program Age.exe, provided by Dr. R. Grün (Grün, 1994) using the dose rate conversion factors of Nambi and Aitken (1986). The U and Th contents were measured by ICP-MS, and K was measured using XRF. Water contents were measured immediately after sampling. An alpha efficiency of $0.1 \pm 0.02$ (Richardson et al., 1997) was used. The radioactivity data and the resulting dose rates are given in Table 1.

\section{Results and discussion}

The $D_{\mathrm{E}}$ values and the calculated IRSL and TL dates of the samples are shown in Table 2. The dates for L1 loess are ranging from 12 to 41 ka by IRSL and from 12 to $59 \mathrm{ka}$ by TL. Figure 5 plots IRSL and TL dates versus distance from the top of the section. Except for one sample (SJP-6), the IRSL and TL dates of samples from the upper $12 \mathrm{~m}$ of the section agree with each other, but for samples from the lower $9 \mathrm{~m}$ of the section the IRSL dates are younger than the TL dates. This indicates that both dates are valid down to a depth of $12 \mathrm{~m}$, although the reason for the TL age overestimation of SJP-6 is unknown.

A comparison of the IRSL and TL $D_{\mathrm{E}}$ values for the same samples (Fig. 6-a) shows that the IRSL $D_{\mathrm{ES}}$ appear to underestimate the TL $D_{\mathrm{ES}}$, but are close to a $1: 1$ ratio up to $200 \mathrm{~Gy}$. Beyond the TL $D_{\mathrm{E}}$ value of $200 \mathrm{~Gy}$, however, the difference between the IRSL and TL $D_{\mathrm{ES}}$ increases. Two types of discrepancy between IRSL and TL $D_{\mathrm{E}}$ values have been reported. The first was constant IRSL underestimation ; Musson and Wintle (1994) and Musson et al.

Table 1 Dose rate data for loess samples from Shajinping section, Lanzhou

\begin{tabular}{lcccccccc}
\hline sample & $\begin{array}{c}\mathrm{U} \\
(\mathrm{ppm})\end{array}$ & $\begin{array}{c}\mathrm{Th} \\
(\mathrm{ppm})\end{array}$ & $\mathrm{K}(\%)$ & $\begin{array}{c}\text { water } \\
(\%)\end{array}$ & $\mathrm{D}_{\alpha}{ }^{*}(\mathrm{mGy} / \mathrm{yr})$ & $\mathrm{D}_{\beta}(\mathrm{mGy} / \mathrm{yr})$ & $\begin{array}{c}\mathrm{D}_{\gamma}+\mathrm{D}_{\text {cos }} \\
(\mathrm{mGy} / \mathrm{yr})\end{array}$ & $\begin{array}{c}\text { Dose Rate } \\
(\mathrm{mGy} / \mathrm{yr})\end{array}$ \\
\hline SJP-1 & 3.2 & 16.2 & 2.1 & 8.4 & $1.7 \pm 0.4$ & $2.4 \pm 0.1$ & $1.7 \pm 0.1$ & $5.8 \pm 0.5$ \\
SJP-5 & 2.6 & 12.4 & 2.2 & 7.2 & $1.4 \pm 0.3$ & $2.3 \pm 0.1$ & $1.5 \pm 0.1$ & $5.1 \pm 0.4$ \\
SJP-6 & 2.6 & 12.3 & 2.1 & 8.0 & $1.4 \pm 0.4$ & $2.2 \pm 0.1$ & $1.4 \pm 0.1$ & $4.9 \pm 0.4$ \\
SJP-9 & 2.6 & 12.9 & 2.1 & 8.1 & $1.4 \pm 0.3$ & $2.2 \pm 0.1$ & $1.4 \pm 0.1$ & $5.0 \pm 0.4$ \\
SJP-11 & 2.9 & 12.9 & 2.1 & 9.1 & $1.4 \pm 0.3$ & $2.2 \pm 0.1$ & $1.4 \pm 0.1$ & $5.1 \pm 0.4$ \\
SJP-12 & 2.5 & 11.2 & 2.1 & 6.9 & $1.3 \pm 0.3$ & $2.2 \pm 0.1$ & $1.3 \pm 0.1$ & $4.8 \pm 0.4$ \\
SJP-13 & 2.5 & 11.7 & 2.1 & 6.4 & $1.3 \pm 0.3$ & $2.2 \pm 0.1$ & $1.4 \pm 0.1$ & $4.9 \pm 0.4$ \\
SJP-14 & 2.5 & 11.8 & 2.0 & 6.3 & $1.3 \pm 0.3$ & $2.1 \pm 0.1$ & $1.3 \pm 0.1$ & $4.8 \pm 0.4$ \\
SJP-16 & 2.5 & 11.6 & 2.0 & 6.5 & $1.3 \pm 0.3$ & $2.1 \pm 0.1$ & $1.3 \pm 0.1$ & $4.8 \pm 0.4$ \\
SJP-17 & 3.0 & 13.6 & 2.0 & 8.4 & $1.5 \pm 0.3$ & $2.2 \pm 0.1$ & $1.4 \pm 0.1$ & $5.1 \pm 0.4$ \\
\hline *a-value of $a=0.1 \pm 0.02$ & is tentatively used
\end{tabular}

Table 2 Equivalent doses and IRSL and TL dates of loess from Shajinping section, Lanzhou

\begin{tabular}{lcccccccc}
\hline sample & $\begin{array}{c}\text { depth } \\
(\mathrm{m})\end{array}$ & $\begin{array}{c}\text { Dose Rate } \\
(\mathrm{mGy} / \mathrm{yr})\end{array}$ & IRSL $\mathrm{D}_{\mathrm{E}}$ (Gy) & TL $\mathrm{D}_{\mathrm{E}}(\mathrm{Gy})$ & IRSL date (ka) & TL date (ka) \\
\hline SJP-1 & 1.3 & $5.8 \pm 0.5$ & $68 \pm 12$ & $69 \pm 13$ & $11.6 \pm 2.3$ & $11.8 \pm 2.4$ \\
SJP-5 & 2.85 & $5.1 \pm 0.4$ & $113 \pm 11$ & $155 \pm 30$ & $21.9 \pm 2.8$ & $30.1 \pm 6.3$ \\
SJP-6 & 4.05 & $4.9 \pm 0.4$ & $136 \pm 12$ & $277 \pm 48$ & $27.3 \pm 3.3$ & $55.6 \pm 10.6$ \\
SJP-9 & 7.2 & $5.0 \pm 0.4$ & $136 \pm 8$ & $158 \pm 20$ & $27.1 \pm 2.7$ & $31.5 \pm 4.7$ \\
SJP-11 & 9.05 & $5.1 \pm 0.4$ & $151 \pm 19$ & $192 \pm 60$ & $29.8 \pm 4.5$ & $37.7 \pm 12.2$ \\
SJP-12 & 9.75 & $4.8 \pm 0.4$ & $165 \pm 10$ & $174 \pm 29$ & $34.5 \pm 3.5$ & $36.3 \pm 6.8$ \\
SJP-13 & 12 & $4.9 \pm 0.4$ & $126 \pm 15$ & $150 \pm 29$ & $26.0 \pm 3.8$ & $30.8 \pm 6.5$ \\
SJP-14 & 13.1 & $4.7 \pm 0.4$ & $123 \pm 22$ & $219 \pm 40$ & $25.6 \pm 5.1$ & $45.6 \pm 9.2$ \\
SJP-16 & 16.9 & $4.7 \pm 0.4$ & $193 \pm 15$ & $278 \pm 48$ & $40.6 \pm 4.7$ & $58.5 \pm 11.2$ \\
SJP-17 & 19.3 & $5.1 \pm 0.4$ & $176 \pm 21$ & $294 \pm 70$ & $34.2 \pm 5.0$ & $57.2 \pm 14.5$ \\
\hline
\end{tabular}




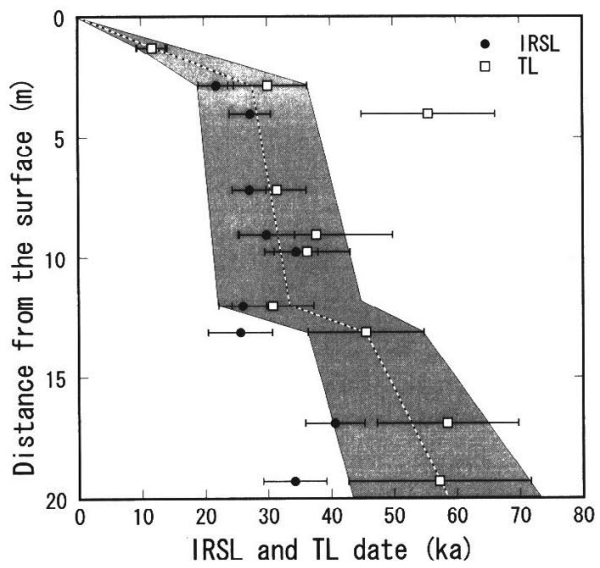

Fig. 5 IRSL and TL dates versus distance from the top of the outcrop at Shajinping Hatching shows the range of depositional ages of loess with depth in the section; the dotted line shows a probable age-depth relationship, based on IRSL and TL dates and error ranges.

(1994) reported constant IRSL underestimation of around 15\% for Czech loess, and of around $12 \%$ for Chinese loess. They assumed that the difference was due either to preheating that was not sufficient to isolate the stable IRSL signal, or to incomplete zeroing of the TL signal at deposition. The second type of discrepancy that has been reported was that IRSL $D_{\text {E }}$ values reached a steady-state level that was lower than those of TL $D_{\mathrm{E}}$ values (Richardson et al., 1997). Our results are similar to the latter ; the steady-state level of the IRSL was about 200 Gy (Fig. 6-a), which is equivalent to about 40 ka (Fig. 6-b). Hence, the depositional history of the loess in the Shajinping section is interpreted using both IRSL and TL dates for sediments up to a depth of $12 \mathrm{~m}$, but only TL dates for strata below $12 \mathrm{~m}$.

The hatching in Figure 5 shows the range of depositional ages of loess according to depth in the Shajinping section, and the dotted line shows a probable age-depth relationship for the section, based on the IRSL and TL dates and the error ranges. The TL date of $57 \pm 15 \mathrm{ka}$ for sample SJP-17, close to the bottom of the loess, indicates that loess deposition on the T2 terrace at Lanzhou began at about $60 \mathrm{ka}$.

It is probable that the loess deposition rate
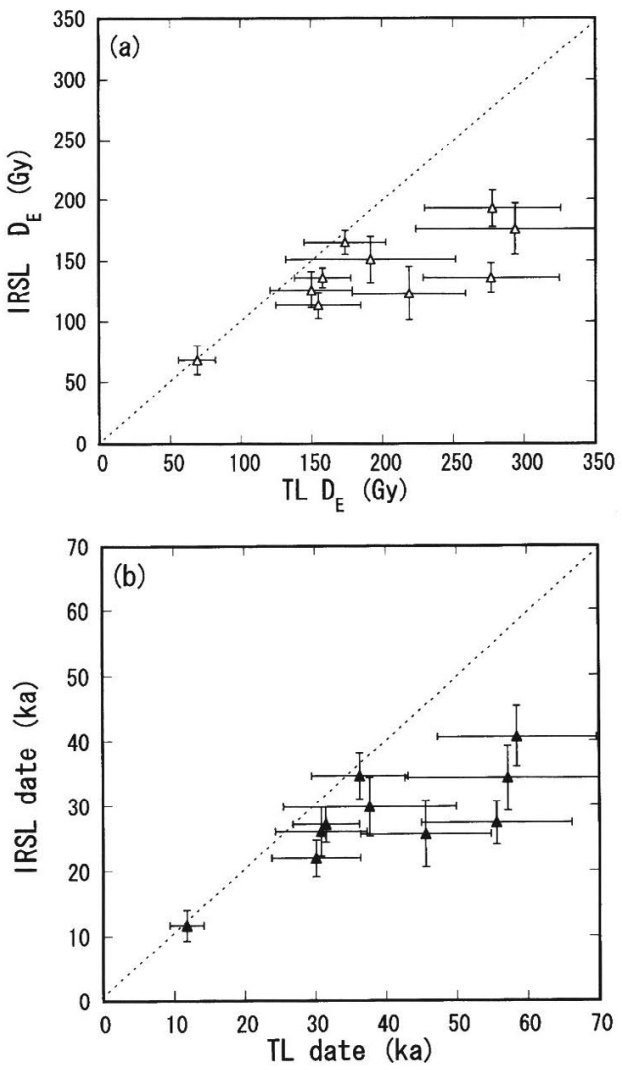

Fig. 6 Comparison of IRSL and TL dating methods

(a) Comparison of IRSL and TL $D_{\mathrm{F}}$ values

(b) Comparison of IRSL and TL dates

The dotted line shows a $1: 1$ relationship.

has changed several times during the last $60 \mathrm{ka}$ (Fig. 5). The deposition rate appears to have been higher around $30 \mathrm{ka}$, and between 50 and $60 \mathrm{ka}$, although the evidence for the latter is not strong because of the large error in the TL dates. On the other hand, the rate was lower between 12 and $25 \mathrm{ka}$, and between 30 and $45 \mathrm{ka}$. The deposition rate of loess is generally thought to be higher during cold intervals, such as marine isotope stages (MIS) 2 and 4. However, our results imply that the highest deposition rate occurred during late MIS 3.

\section{Conclusions}

A low saturation value of the IRSL $D_{\mathrm{E}}$ of about $200 \mathrm{~Gy}$ was obtained for loess samples from Lanzhou, which correlates with an age of about $40 \mathrm{ka}$. This saturation level of the IRSL 
$D_{\mathrm{ES}}$ limits the effectiveness of IRSL dating of loess to ages less than about $40 \mathrm{ka}$.

The IRSL and TL dates of loess samples from the Shajinping section, Lanzhou, indicate that the loess deposition rate has varied during the last $60 \mathrm{ka}$. A very high loess deposition rate was obtained for late MIS 3, whereas a lower rate was obtained for MIS 2.

\section{Acknowledgements}

We would like to thank T. Nagatomo and Y. Kitashiro for the use of the Daybreak system, H. Kawahata, K. Minoshima, and T. Watanuki for helping with the uranium and thorium analyses. Potassium contents were measured by K. Yoshimitsu of HORIBA Ltd. We also thank Li Jijun, Pan Baoton, M. Torii for their field assistance, and D. Eden for valuable comments. This work was partially supported by a Grant in Aid for the Scientific Research from the Ministry of Education, Science and Culture, Japan for S. T. (No. 09874109 and No. 11780076).

\section{References}

Burbank, D.W. and Li, J.-J. (1985) Age and paleomagnetic significance of the loess of Lanzhou. Nature, 316, 429-431.

Brumby, S. (1992) Regression analysis of ESR/TL dose-response data. Nucl. Tracks Radiat. Meas., 13, 177-184.

Fang, X.-M., Li, J.-J., Derbyshire, E., FitzPatrick, E. A., and Kemp, R. (1994) Micromorphology of the Beiyuan loess-paleosol sequence in Gansu Province, China : Geomorphological and paleoenvironmental significance. Palaeogeog., Palaeoclimat., Palaeoecol., 111, 289-303.

Fang, X.-M., Ono, Y., Fukusawa, H., Pan, B.-T., Li, J.-J., Guan, D.-H., Oi, K., Tsukamoto, S., Torii, M. and Mishima, T. (1999) Asian summer monsoon instability during the past 60,000 years : magnetic susceptibility and pedogenic evidence from the western Chinese Loess Plateau. Earth Planet. Sci. Lett., 168, 219-232.

Forman, S.L., Lepper, K. and Pierson, J. (1994) Limitations of infra-red stimulated luminescence in dating high arctic marine sediments. Quat. Sci. Rev.
(Quat. Geochronol.), 13, 545-550.

Frechen, M. (1999) Upper Pleistocene loess stratigraphy in Southern Germany. Quat. Sci. Rev. (Quat. Geochronol.), 18, 243-269.

Fukusawa, H. and Yamada, K. (1998) High resolution multi-proxy records of Asian monsoon activities from sediments over last 75,000 years. Jour. Geogr., 106, 240-248. (J)

Grün, R. (1994) Age.exe. computer program for luminescence age calculations. RSES, Canberra.

Huntley, D. J., Short, M.A. and Dunphy, K. (1996) Deep traps in quartz and their use for optical dating. Can. Jour. Phys., 74, 81-91.

Li, J.-J., Zhu, J.-J., Kuang, J.-C., Chen, F.-H., Fang, X.-M., Mu, D.-F., Cao, J.-X., Tang, L.-Y., Zhang, T. and Pan, B.-T. (1990) Comparison of Lanzhou loess section of last glacial epoch with Antarctic Vostok ice core. Sci. China, ser. B, 10, 1086-1094.

Musson, F.M. and Wintle, A.G. (1994) Luminescence dating of the loess profile at Dolni Vestonice, Czech Republic. Quat. Sci. Rev. (Quat. Geochronol.), 13, 411 $-416$.

Musson, F.M., Clarke, M.L. and Wintle, A.G. (1994) Luminescence dating of loess from the Liujiapo Section, Central China. Quat. Sci. Rev. (Quat. Geochronol.), 13, 407-410.

Nambi, K.S.V. and Aitken, M.J. (1986) Annual dose comversion factors for TL and ESR dating. Archaeometry, 28, 202-205.

Richardson, C.A., McDonald, E.V. and Busacca, A.J. (1997) Luminescence dating of loess from the northwest United States. Quat. Sci. Rev. (Quat. Geochronol.), 16, 403-415.

Stokes, S. (1992) Optical dating of young (modern) sediments using quartz : results from a selection of depositional environments. Quat. Sci. Rev. (Quat. Geochronol.), 11, 153-159.

Tsukamoto, S., Fukusawa, H., Ono, T., Ooi, K. and Fang, X.-M. (1999) Infrared stimulated luminescence dating of Chinese loess. Bull. Nat. Mus. Japan. Hist., 81, 503-515. (J+E)

Yamada, K., Fukusawa, H., Fang, X.-M., Pan, B.-T., Li, J.-J. and Iwata, S. (1999) High-resolution multiproxy records of Asian monsoon activities from terrestrial sediments over the last 75,000 years. Chi. Sci. Bull., 44, Suppl., 223-229.

$(\mathrm{J}+\mathrm{E})$ in Japanese with English abstract, $(\mathrm{J})$ in Japanese 


\title{
中国，蘭州のレス堆積物のルミネッセンス年代測定
}

\author{
塚本 すみ子*1・福澤 仁之*1・ 小野 有五*2・方 小敏*3
}

〔要旨〕

中国甘肃省蘭州の T2 段丘上に堆積しているレス堆積 物の年代測定を，赤外励起ルミネッセンス（IRSL）法お よび熱ルミネッセンス（TL）法を用いて行った．IRSL 年代測定に打いては，ガンマ線照射後に，熱的に不安定 な IRSL 信号を除去するプレヒートを行うことが不可欠 である. 今回用いたレス試料に最適なプレヒート条件を 設定するため, $120^{\circ} \mathrm{C}$ 抒よび $160^{\circ} \mathrm{C}$ でプレヒート実験を

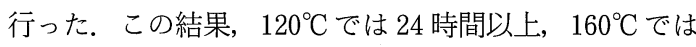
1.5 時間と 6 時間の間で照射した試料と未照射の試料の 信号強度比が一定（プラトー）に達した. しかし， $160^{\circ} \mathrm{C}$ でプレヒートした試料は, IRSL 信号強度がガンマ線照 射に対していったんは増加するものの, すぐに減少して しまい, 年代測定に必要な等価線量の推定を行うことが
できなかった. そこで，すべての試料を $120^{\circ} \mathrm{C}$ で 96 時間 のプレヒートを行うことにした.

得られた IRSL および TL 年代は, 厚さ $22 \mathrm{~m}$ のレス 堆積物の上位 $12 \mathrm{~m}$ では, 1 試料を除いて誤差の範囲で 一致していた.一方, 下位の $9 \mathrm{~m}$ においては, IRSL年代 が TL年代より若くなった。これは, 試料の年代が IRSL 年代測定の上限を超えてしまったためと考えられ る。年代測定結果より，蘭州の $\mathrm{T} 2$ 段丘上のレスは約 6 万年前から堆積を開始したと考えられる。また，この間 に数回の堆積速度の变化があったことが示唆された. 最 大の堆積速度を示したのは酸素同位体ステージ (MIS) 3 にあたる約 3 万年前であり, MIS 2 の時期の堆積速度は 小さかったと考えられる。

*1 東京都立大学大学院理学研究科地理科学専攻 $\mathbf{T} 192-0397$ 八王子市南大沢 1-1. E-mail :

*2 北海道大学大学院地球環境科学研究科 $\overline{\mathbf{T}} 060-0810$ 札幌市北区北 10 条西 5 丁目.

${ }^{*} 3$ 蘭州大学地理学系 甘肃省蘭州 730000 (中華人民共和国). 